\title{
A Case of Primary Ewing Sarcoma of the Strap Muscle
}

\author{
Dongbin Ahn ${ }^{1}$, Jin Ho Sohn ${ }^{1}$, and Ji Yun Jeong ${ }^{2}$ \\ ${ }^{1}$ Departments of Otolaryngology-Head and Neck Surgery, ${ }^{2}$ Pathology, School of Medicine, Kyungpook National University, \\ Daegu, Korea
}

\author{
피대근에 발생한 원발성 유잉 육종 1 예 \\ 안동빈 $^{1} \cdot$ 손진호 ${ }^{1} \cdot$ 정지윤 $^{2}$

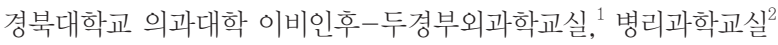

\author{
Received January 21,2016 \\ Revised March 1,2016 \\ Accepted March 9, 2016 \\ Address for correspondence \\ Dongbin Ahn, MD \\ Department of Otolaryngology- \\ Head and Neck Surgery, \\ School of Medicine, \\ Kyungpook National University, \\ 130 Dongdeok-ro, Jung-gu, \\ Daegu 41944, Korea \\ Tel +82-53-200-2792 \\ Fax +82-53-200-2027 \\ E-mail godlikeu@naver.com
}

\begin{abstract}
Ewing sarcoma (ES) is an uncommon type of malignancy that arises most frequently in the long bones of the extremities and the pelvis. Primary ES of the head and neck region is extremely rare, accounting for only $1-9 \%$ of all ES cases. Because ES typically affects children and young adults, it is of paramount importance to differentiate such tumors from benign lesions or congenital neck masses, particularly in cases where lesions arise primarily from the soft tissue rather than from the bone. We encountered a case of ES of the strap muscle in a 4-year-old boy that manifested as an isolated midline neck mass mimicking a thyroglossal duct anomaly. We report this case along with a brief literature review.
\end{abstract}

Korean J Otorhinolaryngol-Head Neck Surg 2017;60(3):135-9

Key Words Ewing sarcoma $\cdot$ Head and neck neoplasm $\cdot$ Neck muscle.

\section{서 론}

유잉 육종은 뼈나 연조직에서 발생하는 비교적 드문 악성 종양으로, 그 기원은 아직 확실치 않으나 조직학적 소견, 면 역화학염색의 유사성과 염색체 변이 등의 공통점 때문에 말 초원시신경외배엽성 종양과 동일한 기원을 갖는 것으로 추정 되고 있다. ${ }^{1)}$ 이러한 유잉 육종은 전형적으로 소아나 젊은 성인 에서 사지 장골과 골반에서 발생하며, 두경부에 원발성으로 발 생하는 경우는 전체 유잉 육종의 1 9\% 정도를 차지하고 있 다. ${ }^{2,3)}$ 따라서 두경부 유잉 육종은 수술 전까지 해당 연령대에 흔하게 발생하는 다른 종물로 오인되기도 하며, 이로 인해 적 절한 진단이나 치료가 늦어질 수 있다. ${ }^{4,5)}$ 또한, 유잉 육종이 두경부 영역에서 발생하는 경우에도 대부분 경추나 구개골, 하악골 등의 골조직에서 발생하기 때문에, 경부 연조직에서 발생하는 경우 그 감별진단으로 유잉 육종을 고려하기는 매 우 힘들며, 그에 대한 연구 역시 매우 빈약한 실정이다.,6)

저자들은 4세 남아에서 갑상설관 낭종과 유사한 양상으로
피대근에서 발생한 원발성 유잉 육종 1예를 경험하였기에 이 를 문헌고찰과 함께 보고하고자 한다.

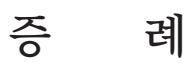

4세 남아가 2개월 전 우연히 발견된 전경부 종물을 주소로 내원하였다. 내원 당시 종물은 약 $2.5 \times 2.0 \mathrm{~cm}$ 크기로 갑상연 골과 설골 사이의 높이에, 그리고 경부 정중앙에서 약 $2.0 \mathrm{~cm}$ 가량 좌측에 위치하였으며, 환아는 이에 대해 특별한 증상을 호소하지는 않았다. 이전 타 병원에서는 해당 종물의 신체 검 사 및 초음파 검사를 통해 갑상설관 낭종을 의심한 상태였다. 본원에서 시행한 신체 검진 상 연하 시 종물이 수직으로 움직 이는 것을 확인할 수 있었으며, 종물의 위치와 이런 소견을 근거로 저자들 또한 갑상설관 낭종을 우선 의심하였다. 그러 나 종물은 일반적인 갑상설관 낭종보다 매우 단단하고 주변 조직과 경계가 불분명하였으며, 이에 갑상설관 낭종에서 추 가적으로 발생한 종양이나 림프종 등의 가능성을 배제하기 

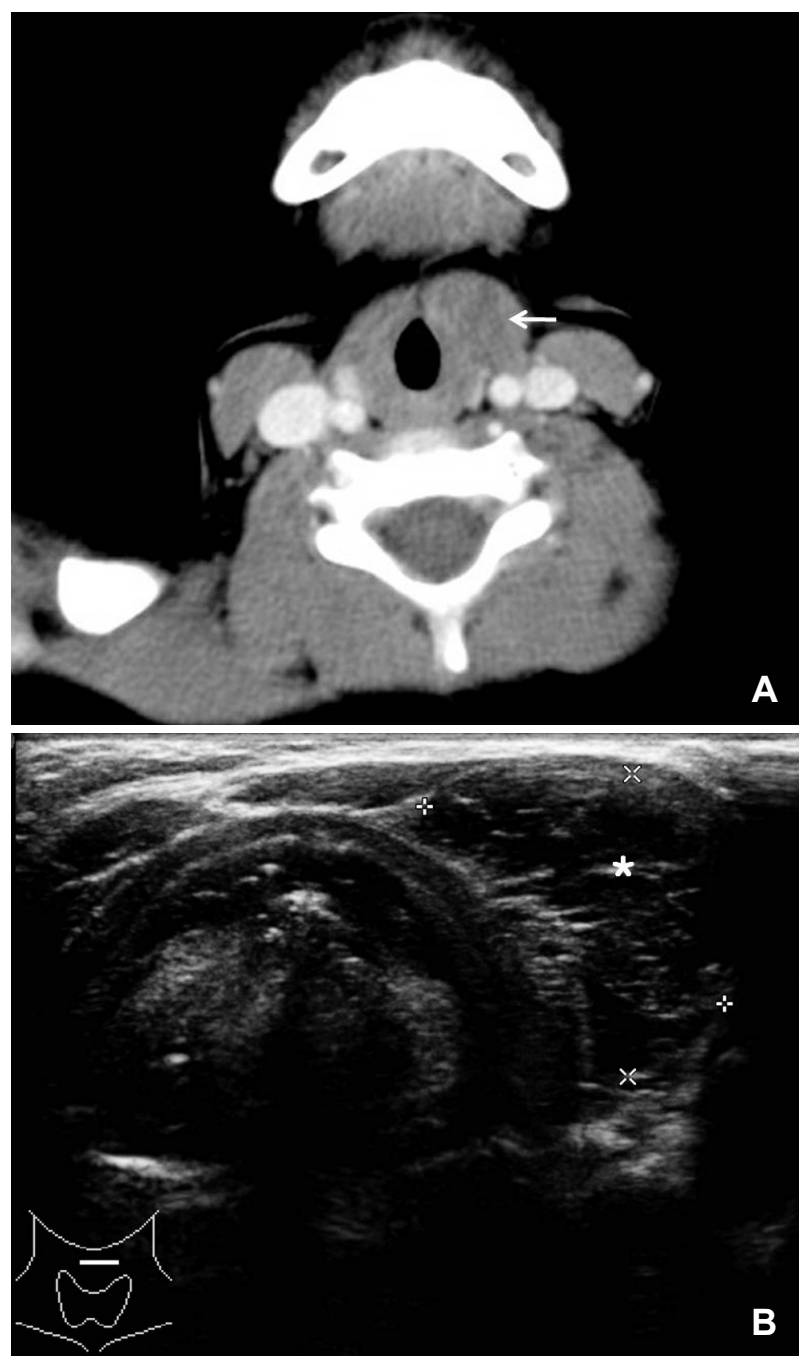

Fig. 1. Computed tomography scan (A) and ultrasonography image (B). A poorly circumscribed mass lesion (arrow and asterisk) measuring approximately $2.5 \times 2 \mathrm{~cm}$ and involving the strap muscle is visible in the left anterior neck region.

위해 초음파 유도 하 세침흡인검사 및 경부 전산화단층촬영 을 시행하였다.

전산화단층촬영에서는 설골의 좌측 하방에서 갑상설골근 과의 경계가 불분명하고, 상대적으로 저음영을 보이는 $2.5 \times 2$ $\mathrm{cm}$ 크기의 종물을 확인할 수 있었으며, 영상의학과 판독 상 비정형적이긴 하나 역시 갑상설관 낭종의 가능성이 우선 고 려된다고 하였다(Fig. 1A). 초음파 검사 역시 전산화단층촬영 과 동일한 판독 소견이었으나(Fig. $1 \mathrm{~B}$ ), 세침흡인검사에서는 양성의 갑상설관 낭종의 소견과는 전혀 다른 매우 심한 상피 증식(epithelial proliferation)의 소견과 함께, 해당 세포의 이 형성(atypia)과 유사분열(mitosis) 소견도 관찰되어 종양성 병 변의 가능성이 크다는 보고를 받았다.

이러한 결과들을 바탕으로 정확한 진단 및 치료를 위해 경 부 절개를 통한 완전 절제를 시행하기로 하였으며, 수술 중 동
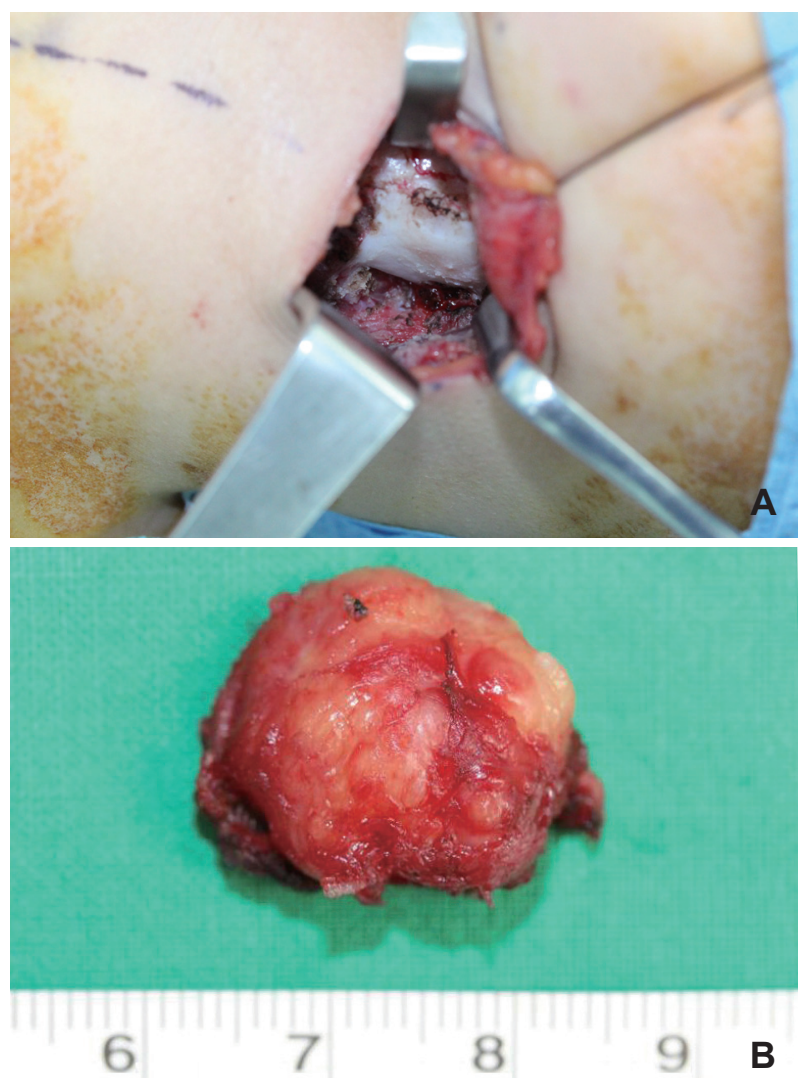

Fig. 2. Photographs of the surgical field (A) and specimen (B) after excision. The perichondrium of the thyroid cartilage ala was removed along with the mass. An uncapsulated yellowish tumor with an irregular surface is visible.

결절편 조직검사를 통해 필요 시 추가적인 제거를 하기로 계 획하였다. 수술 소견 상 종물은 전산화단층촬영에서 의심되 었던 것과 같이 좌측 갑상설골근에 중심을 두고 있었으며, 갑 상설골근의 내측으로는 갑상연골과 유착되어 있는 소견을 보 였다. 이에 저자들은 갑상설골근 및 갑상연골의 외연골막을 포함하여 종물을 완전절제 하였으며(Fig. 2), 동결절편검사에 도 특정 진단은 내릴 수 없으나, 단순 갑상설관 낭종보다는 세 포 분열빈도가 높은 종양성 병변이라는 답변을 확인하였다.

수술 후 환아는 특별한 합병증 없이 양호한 경과를 보였다. 최종 조직검사 상 종양의 크기는 $2.0 \times 1.7 \mathrm{~cm}$ 였으며, 헤마톡 실린-에오신 염색 상 원형소세포종양(small round cell tumor) 의 일종으로 확인되었다(Fig. 3). 절제 변연은 모두 음성이었 으나 갑상연골과 유착을 보였던 심부 변연의 경우 $0.5 \mathrm{~cm}$ 이 내로 확인되었다. 감별진단을 위한 면역화학염색에서 vimentin, CD99, Ki-67 등에 양성, cytokeratin, myo D1, epithelial membrane antigen, $\mathrm{CD} 56$, desmin 등에 음성 소견을 보여 유 잉 육종에 합당한 소견을 보였으며(Fig. 4), 이후 추가적인 EWS 유전자의 형광제자리부합법 검사(fluorescent in-situ hybridization)에서 양성으로 확인되어 최종적으로 골외 유잉 육종으 
로 진단되었다.

이후 환아는 소아혈액종양과로 전과되어 양성자 방출 단층 촬영, 흥부 전산화단층촬영, 뇌 자기공명영상, 골 스캔 및 골 수천자 등의 검사를 시행하였으나, 원발 부위를 의심할 만한 다른 병변이나 원견 전이의 소견은 없었다. 치료로는 vincristine/doxorubicin/cyclophosphamide 조합의 유도항암화학 요법 6회와 $5040 \mathrm{cGy}$ 의 방사선 치료, 그리고 vincristine/doxorubicin/ifosphamide/etoposide 조합의 유지 항암요법 8회를 시행받았으며, 현재까지 약 12 개월 동안 재발 소견 없이 추적

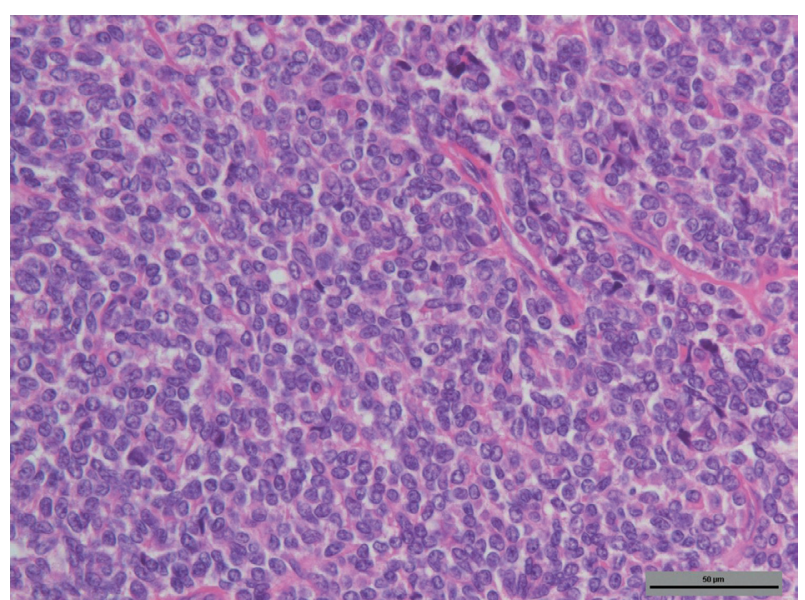

Fig. 3. The tumor is composed of monotonous cells containing round to ovoid vesicular nuclei with fine chromatin, inconspicuous nucleoli, and a small amount of cytoplasm; these features are consistent with those of small round cell tumors (hematoxylin and eosin staining; magnification: $\times 400$ ).
관찰 중에 있다.

\section{고 찰}

유잉 육종은 전형적으로 소아나 젊은 성인에서 주로 발생 하지만 1 년에 인구 백만 명당 2.9명만이 발생할 정도로 그 빈 도가 매우 낮다. ${ }^{7)}$ 1999년 Allam 등6)이 발표한 24예의 두경부 유잉 육종에 대한 연구를 살펴보면, 두경부 유잉 육종은 상악 (37.5\%), 하악(25.0\%), 안와(17.0\%), 두개(12.5\%) 등의 빈도로 호발하였으며, 두경부 연조직에서 발생한 경우는 한 예도 없 었다. 2010년 Whaley 등 ${ }^{3}$ 에 의해 발표된 9예의 유잉 육종을 대상으로 한 연구에서도 오직 1예만이 후경부 근육에서 발 생한 경우였으며, 나머지 모든 경우는 역시 두경부 골조직에 서 기원한 경우였다. 게다가 이번 증례와 같이 골외성 유잉 육종이 경부 피대근에서 발생한 경우는 영문 검색 엔진 및 한국의학논문데이터베이스 등을 통한 국내외 문헌 검색에서 도 확인할 수 없었다.

이처럼 두경부 유잉 육종이 연조직에서 발생하는 경우, 그 드문 빈도와 비교적점진적인 경과, 그리고 유잉 육종을 고려 할 만한 특징적인 증상이나 신체 검진 소견이 없다는 점 때 문에 보다 높은 빈도를 가지는 다른 진단을 우선 고려하게 된다. 실제 경부 연조직에서 발생한 유잉 육종에 대한 국내 증 례 2개를 살펴보면, 수술 전까지는 각각 level IV 영역에 발생 한 신경성 종양과 level II 영역의 염증성 결절이나 림프종을 우선 의심하였으며, 종양 적출 또는 절제 생검 후 특수염색

Fig. 4. Immunohistochemical tumor staining indicates positivity for CD99 and $\mathrm{Ki}-67$, but negativity for cytokeratin and desmin, suggestive of an ewing sarcoma (magnification, $\times 200$ ).
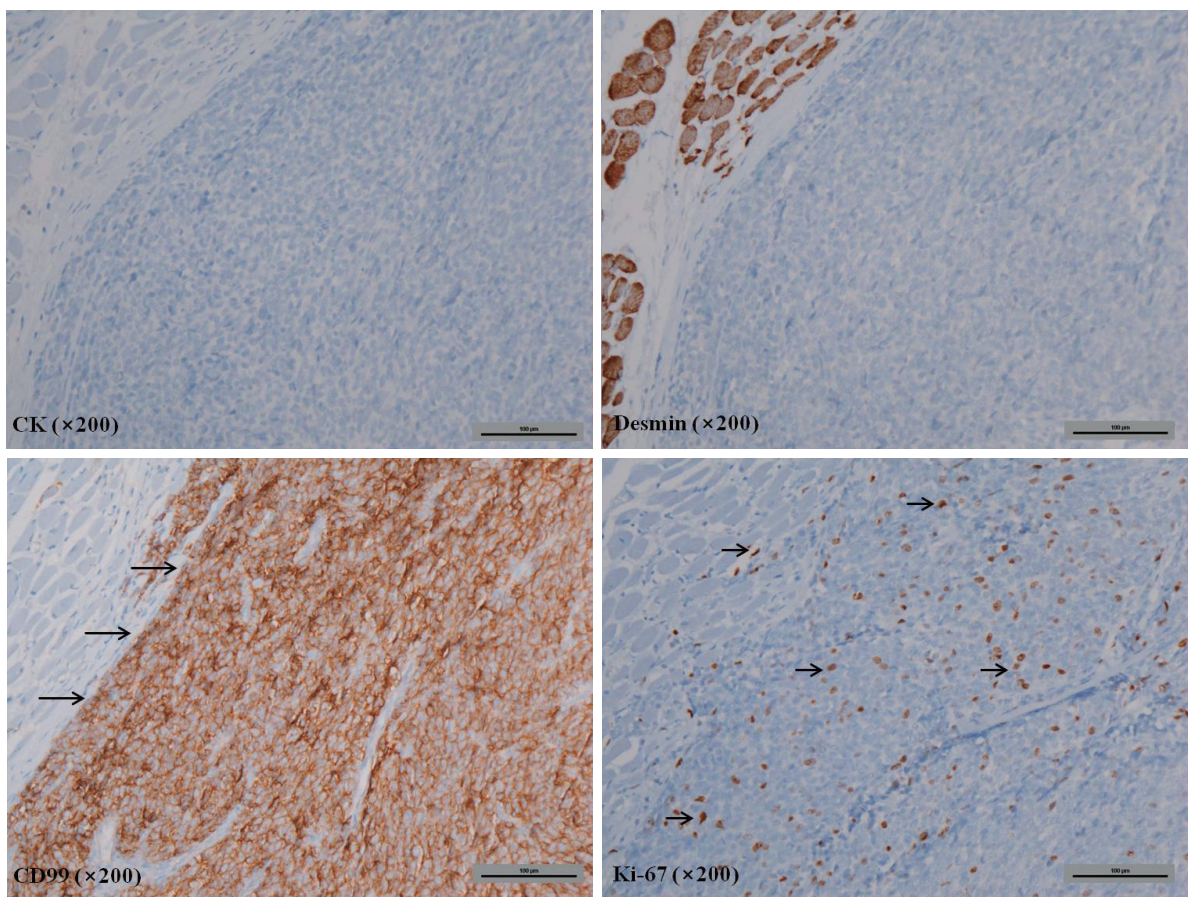
을 통해서 비로소 유잉 육종을 진단할 수 있었다. ${ }^{24)}$ 만약 이 같은 상황에서 술자가 수술 전 강한 의심을 갖고 적극적인 진단적 접근을 하지 않는다면 때로는 수술을 통한 조직학적 확진이 늦어질 수 있다. 본 증례에서도 수술 전까지는 유잉 육종의 가능성을 전혀 고려할 수 없었는데, 양성 갑상설관 낭종에서는 일반적으로 수술 전 세침흡인검사가 권장되지는 않지만, 기본적인 종물의 특성을 확인하기 위한 신체 검진 소견을 바탕으로 추가적인 세포검사를 시행함으로써 악성 종양의 가능성을 충분히 염두에 두고 환자 및 보호자에게 즉각적인 수술적 제거를 권유할 수 있었다.

유잉 육종의 병리조직 검사 소견으로는 헤마톡실린-에오 신 염색 상 원형소세포종양의 양상을 보이며, 이러한 경우 원 형소세포종양의 양상을 보이는 결합조직성 원형소세포종양 (desmoplastic small round cell tumor), 횡문근육종(rhabdomyosarcoma), 신경아세포종(neuroblastoma), 림프종 등 과의 감별이 필요하다. 이를 위한 추가적인 면역조직화학염색 중 desmin에서 음성인 경우 횡문근육종과 결합조직성 원형 소세포종양과의 감별이 가능하며, 이에 더하여 CD99에서 양 성인 경우 유잉 육종을 강하게 의심할 수 있다. 하지만 CD99 에서 양성을 보이는 것 역시 유잉 육종에서 특징적인 소견은 아니어서, 이러한 소견을 바탕으로 최종적으로 형광제자리부 합법 검사나 중합효소 연쇄반응(polymerase chain reaction) 을 시행하게 되며, 이를 통해 염색체 11 번과 22 번의 전위로 인 한 22번 염색체의 EWS 유전자와 11번 염색체의 FLI1 유전자 의 융합을 확인되면 비로소 유잉 육종으로 확진할 수 있다.

조직검사를 통해 최종적으로 유잉 육종이 진단되면 일반적 인 악성 종양에서와 같이 종양의 진행 정도를 평가해야 한다. 유잉 육종은 혈행성 전이를 잘 일으켜 진단 당시 약 $25 \%$ 환 자에서 원격전이를 동반하며, 그 호발 부위는 폐, 빼, 골수 순 으로 알려져 있기 때문에 양성자 방출 단층촬영, 흥부 전산 화단층촬영, 골 스캔, 골수천자 등의 검사가 필요하다. ${ }^{8)}$ 유잉 육종에 대한 병기 시스템은 American Joint Committee on Cancer의 원발성 골종양 관한 TNM 병기를 사용할 수 있는 데, 해당 병기와 적용되는 치료와의 상관관계가 부족하고 본 증례처럼 골외성 유잉 육종도 있기 때문에, 실제 치료 적용 에 있어서는 국소성과 전이성으로 단순히 구분하여 사용되 고 있다. ${ }^{699}$ 본 증례의 경우에는 경부 유잉 육종의 발생 빈도 가 매우 드물고, 또한 현재까지 발생이 보고된 적 없는 피대근 의 유잉 육종으로 확인되었기 때문에 혹시 해당 병변이 원발 병변이 아닌 전이성 병변인지 확인하기 위해 전신적인 영상 검사 및 골수 검사 등을 시행하였으나, 경부 병변 이외의 다 른 원발 또는 전이 병소를 의심할 소견은 찾을 수 없었으며, 최종적으로 피대근에 발생한 국소성 원발 유잉 육종으로 진
단하게 되었다.

유잉 육종에 대해서는 아직까지 분명하게 정립된 일관된 치 료 방법이 존재하지는 않지만, 대부분의 경우에서 수술, 방사 선 치료, 그리고 항암화학요법을 복합적으로 사용하게 된다. ${ }^{10)}$ 원발 부위에 대한 국소 조절이 장기 예후에 결정적인 역할을 하기 때문에 일반적으로 크기가 작고, 중요 구조물의 보존이 가능하며, 완전 절제에 따른 합병증이 적을 것으로 예상되는 경우는 수술을 통한 종양의 완전 제거가 우선 고려된다. 반 대로 수술에 따른 이환율이 크고 수술이 불가한 경우나, 수 술을 시행하였지만 충분한 변연을 확보하지 못한 경우는 주 치료 또는 수술에 따른 추가 치료로 방사선 치료를 고려하게 된다. ${ }^{311}$ 전신적인 항암화학요법은 국소 치료에 더하여 반드 시 필요한 치료로서 약 6 9개월에 걸쳐 진행되게 되는데, 항 암화학요법이 사용되기 이전 약 $10 \%$ 이던 유잉 육종의 5 년 생 존율이 1960년대 이후 항암화학요법이 사용되기 시작하면서 전이 병소가 없는 국소 질환의 경우 $75 \%$ 까지 향상되었다.7.12)

예후는 환자의 나이, 발생 부위, 진단 당시의 종양의 크기, 전이의 존재 여부, 그리고 항암화학요법에 대한 반응에 따라 매우 다양하게 보고되고 있는데, 전반적으로 약 50 80\%의 5 년 생존율을 나타낸다. ${ }^{2,3,6,7,10)}$ 두경부에 발생한 유잉 육종의 예후에 대해서는 아직까지 연구된 바가 많지는 않으나, 상대 적으로 양호한 예후를 나타내는 것으로 보고되는데, 이는 육 안으로 확인이 가능한 부위에 발생하기 때문에 전이가 일어 나기 전 비교적 종양의 크기가 작을 때 발견이 되고, 그로 인 해 완전한 수술적 제거가 가능한 경우가 보다 흔하기 때문으 로 추정된다. ${ }^{34)}$ 하지만 본 증례에서와 같이 종물 자체는 일 찍 발견된다 하더라도 면밀한 신체 검진과 강한 의심으로 적 극적인 조직학적 진단을 시도하지 않는다면, 유잉 육종의 점 진적인 경과로 인해 양성 종물로 오인되어 진단이 늦어질 가 능성은 충분히 있기 때문에, 임상에서 경부 종물을 주소로 내원하는 환자에 대해 항상 이러한 점을 염두에 두고 접근하 여야 할 것으로 생각된다.

본 증례는 소아에서 발생한 경부 종물의 감별진단에 있어 영상학적 검사에의 지나친 의존보다는 기본적인 신체 검진 소 견을 함께 고려하는 것이 매우 중요하다는 것을 다시 한번 일 깨워 주었으며, 현재까지 보고된 바 없는 피대근에서 발생한 원발성 유잉 육종을 확인하였다는 점에서 특징적이었다. 이 에 저자들은 본 증례를 문헌 고찰과 함께 보고하는 바이다.

\section{REFERENCES}

1) Kim SY, Tsokos M, Helman LJ. Dilemmas associated with congenital ewing sarcoma family tumors. J Pediatr Hematol Oncol 2008;30(1): 4-7.

2) Hong JC, Lee JH, Rha SH, Park HS. A case of cervical ewing sarcoma 
with pulmonary metastasis. Korean J Otorhinolaryngol-Head Neck Surg 2010;53(7):441-3.

3) Whaley JT, Indelicato DJ, Morris CG, Hinerman RW, Amdur RJ, Mendenhall WM, et al. Ewing tumors of the head and neck. Am J Clin Oncol 2010;33(4):321-6.

4) Yoon JH, Son MH, Shin SH, Kim SJ, Park HJ, Park BK, et al. Ewing sarcoma/peripheral primitive neuroectodermal tumor in an adolscence, manifested as isolated cervical mass. Clin Pediatr Hematol Oncol 2011;18(1):70-4.

5) Baik JH, Song YH, Park ES, Choi HS, Shin HY, Choi CH, et al. Combined modality therapy of ewing sarcoma. Korean J Pediatr Hematol Oncol 2004;11:179-86.

6) Allam A, El-Husseiny G, Khafaga Y, Kandil A, Gray A, Ezzat A, et al. Ewing's Sarcoma of the Head and Neck: a retrospective analysis of 24 cases. Sarcoma 1999;3(1):11-5.

7) Balamuth NJ, Womer RB. Ewing's sarcoma. Lancet Oncol 2010;
11(2):184-92.

8) Grier HE. The Ewing family of tumors. Ewing's sarcoma and primitive neuroectodermal tumors. Pediatr Clin North Am 1997;44(4):991-1004.

9) Ahmad R, Mayol BR, Davis M, Rougraff BT. Extraskeletal Ewing's sarcoma. Cancer 1999;85(3):725-31.

10) Schmidt S, Lackner H, Urban C. Ewing sarcoma of the neck. Pediatr Blood Cancer 2010;54(2):339.

11) La TH, Meyers PA, Wexler LH, Alektiar KM, Healey JH, Laquaglia MP, et al. Radiation therapy for Ewing's sarcoma: results from Memorial Sloan-Kettering in the modern era. Int J Radiat Oncol Biol Phys 2006;64(2):544-50.

12) Rosen G, Wollner N, Tan C, Wu SJ, Hajdu SI, Cham W, et al. Proceedings: disease-free survival in children with Ewing's sarcoma treated with radiation therapy and adjuvant four-drug sequential chemotherapy. Cancer 1974;33(2):384-93. 